\title{
LOGISTIC ACTIVITY E-COMMERCE B2C
}

\section{ЛОГІСТИКА ЕЛЕКТРОННОЇ КОМЕРЦЇ̈ МОДЕЛІ В2С}

\section{Nataliia Ilchenko ${ }^{1}$ \\ Olga Freiuk ${ }^{2}$}

DOI: https://doi.org/10.30525/978-9934-588-38-9-28

Abstract. The article explores the development of e-commerce in the B2C, identifying the concepts of «e-commerce enterprise». The current state of the e-commerce market in Ukraine and the introduction of the latest information and communication tools and technologies in trade in Ukraine over the profitability of recent years are analyzed. The importance of distance trading, which is inseparably linked to the overall real offline logistics, is outlined.

In the last few years, logistics providers have increasingly allocated online stores to a single customer segment, with the emergence of specialized companies that cater to online stores and site sales companies. The problem with this study is that, as such, there are no clear scientific approaches to the organization of logistics in e-commerce. Usually, the organization of logistic activity in e-commerce is not investigated as a separate type of logistical activity, but is accepted as identical to the general contours of any supply chain of goods: «production - supply - retail enterprise - consumers».

The authors investigated the approaches of Ukrainian scientists to determining the place of logistics in e-commerce, the role of delivery in the e-commerce system, analyzed the types of logistics activities of the e-commerce enterprise, determined the difference between outsourcing and outsourcing. The main differences in the organization of the process of delivery of goods by own service and under the condition of outsourcing are stated in the work.

${ }^{1}$ Doctor of Economic Science, Associate Professor, Head of the Trade Entrepreneurship and Logistic Department, Kyiv National University of Trade and Economics, Ukraine

${ }^{2}$ Postgraduate, Assistant of the Trade Entrepreneurship and Logistic Department, Kyiv National University of Trade and Economics, Ukraine 
The Logistics Efficiency Index in Ukraine 2010-2018 is analyzed. The complex solutions that are used for online stores - fulliment are investigated. Research methodology is based on the methods of empirical research (observation, comparison, description) and generally logical methods of cognition (analysis, synthesis). The results of the study demonstrate

The necessity to theoretically generalize the essence of logistic activity in e-commerce has been revealed. The problems mentioned above have determined the relevance of the research topic.

\section{1. Ветуп}

Розвиток інформаційних технологій і засобів комунікації, насамперед електронних мереж, додало потужний імпульс для формування нового середовища, активність становлення та інтенсивність використання якого стало важливою особливістю функціонування сучасної торгівлі. Сфера електронної торгівлі в Україні на сьогодні знаходиться на початковому етапі розвитку. Про це свідчить відкриття багатьох Інтернет-магазинів в українському сегменті мережі. Дана тенденція, безсумнівно, є одним з істотних факторів змін у логістичній діяльності підприємств, що ведуть комерційну діяльність через Інтернет.

Електронна торгівля як вид господарсько-торговельної діяльності охоплює весь процес товарно-грошового обміну, реалізованого на основі використання телекомунікаційних мереж та електронних фінансово-економічних інструментів, а не лише ту його частину, яка безпосередньо пов'язана з купівлею-продажем.

Логістична діяльність в електронній торгівлі спирається на інформаційні технології, що забезпечують реалізацію замкненого комерційного циклу, включаючи замовлення товару, здійснення платежів, контроль та участь підприємства торгівлі у ланцюзі поставки товару і здійснюються на основі електронного документообігу та обумовлюють перехід прав власності чи прав використання від однієї юридичної особи до іншої.

Організація логістичної діяльності в електронній торгівлі як невід`ємна частина електронного бізнесу несе скриті резерви конкурентних переваг, адже масштабне та ефективне ії здійснення визначає оптимізацію витрат торговельного підприємства. 


\section{2. Розвиток електронної комерції В2С сегменту}

Із розвитком цифрових технологій змінюються традиційні способи торгівлі, внаслідок чого з'явилося поняття електронної комерції (e-commerce). За останні роки електронна комерція дуже швидко розвинулась. Це викликало велику кількість змін в економіці, яке обумовлено використанням нових методів у веденні бізнесу. Найближчим часом межі між традиційною торгівлею та електронною торгівлею стануть більш розмитими, оскільки все більше компаній та підприємств долучаються до діяльності через Інтернет. Існують різні визначення цього поняття.

Суб'єктом господарської діяльності в електронній комерції та торгівлі є підприємство електронної комерції (торгівлі). Підприємство електронної комерції (ПЕК) - це торговельне підприємство, що здійснює купівлю-продаж товарів, виконання робіт і надання послуг покупцям за допомогою інформаційних технологій і засобів телекомунікації.

Підприємство електронної торгівлі (ПЕТ) - це юридична особа яка здійснює господарську діяльність у сфері електронної купівлі-продажу, реалізації товарів дистанційним способом покупцю, для задоволення його потреб шляхом вчинення електронних правочинів із використанням інформаційно-телекомунікаційних систем та отримання прибутку.

Для ведення господарської діяльності підприємство електронної торгівлі використовують глобальну мережу Інтернет і спеціалізовані сайти - електронні магазини. ПЕТ повинні, окрім технічного відділу, що забезпечує функціонування сайту, існувати відділи закупівель, реклами і маркетингу, служби доставки, склад, бухгалтерія i інші підрозділи, що забезпечують безперебійну роботу всієї системи. Фактично реально працюючий електронний магазин дуже схожий 3 магазином звичайним. За допомогою Інтернет-мережі ПЕК здійснює онлайновий маркетинг, оформлення замовлень, здійснення платежів, підтримку інформації про доставку.

Інформаційна система торговельного підприємства - це технологія ведення підприємства, яка охоплює всі аспекти діяльності підприємства, реалізована за допомогою сучасного високотехнологічного оснащення і спеціалізованого програмного забезпечення. Специфіка інформаційної системи для підприємства електронної комерції в тому, 
що вона функціонує в глобальній мережі Інтернет або використовує комунікації і канали зв'язку для різних аспектів свого функціонування.

Сучасний ринок ставить основним учасником торговельно-грошових відносин покупця. Споживач сьогодні вимагає відмінного обслуговування, широкого асортименту і задоволення будь-яких своїх запитів. I додатково завдяки необмеженим інформаційним можливостям, наданим Інтернетом, покупець проінформований про все, що може йому запропонувати ринок, що збільшує конкуренцію. Головною задачею власників ПЕК стає підтримка такого асортименту і рівня сервісу, щоб привернути до себе найбільшу кількість постійних покупців. Прогнозування, планування, розподіл ресурсів, поповнення запасів повинні цілком відповідати потребам покупця і його запитам.

Метою проектування інформаційної системи сучасного підприємства роздрібної електронної торгівлі є створення інструменту, який дозволить організувати управління магазином так, щоб він працював як єдиний чітко налагоджений механізм [1].

Згідно і проведеними дослідженнями belretail.by, обсяг роздрібного товарообороту електронної торгівлі у світі в 2016-2019 роках зростав в середньому на $20 \%$ в рік, в той же час роздрібні продажі збільшувалися всього лише на 3,5\% в рік. При цьому частка Інтернет-продажів у сфері роздрібної торгівлі зросла з 10,5\% в 2016 році до 16,4\% в 2019 році. Якщо подібна тенденція збережеться, то обсяги світового ринку електронної торгівлі перевищать обсяги традиційної роздрібної торгівлі вже до 2036 році.

Як показали результати дослідження «E-commerce Launch», приблизно 71\% українців користуються Інтернетом. При цьому на другому місці за кількістю запитів в Google стоїть слово «купити» i, як виявилося, кожен другий українець хоча б раз щось купував в Інтернеті [26].

Ринок електронної комерції в Україні становив у 2018 р. 77,9 млрд грн, у т.ч. 65 млрд грн - це електронна торгівля товарами та послугами. За прогнозами у 2019 р. зростання ринку електронної комерції очікувалося не менше, ніж на 25\%, що складало 97 млрд грн в грошовому вираженні, продаж товарів та послуг повинні були досягти 81 млрд грн (рис. 2).

Згідно з даними EVO Group, за 11 місяців 2019 р. українські споживачі витратили на Інтернет-купівлю на 17\% більше, ніж за аналогічний період 2018 р. [4]. 
Nataliia Ilchenko, Olga Freiuk

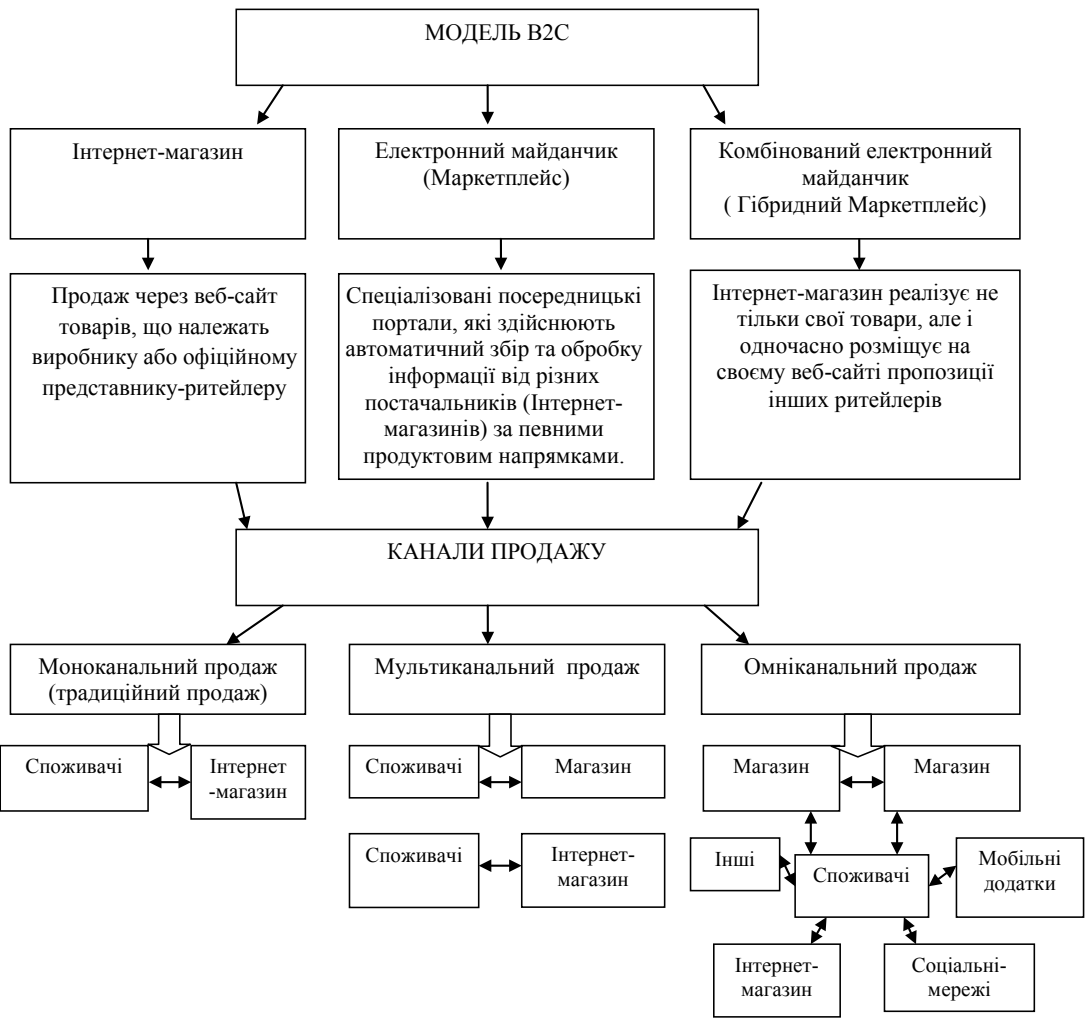

\section{Рис. 1. Класифікація підприсмств електронної торгівлі в секторі В2С та канали їх продажу}

Джерело: систематизовано авторами на основі [24; 25]

За оцінками групи компаній EVO, товарооборот фізичних товарів і послуг, придбаних в Україні онлайн в січні-листопаді 2019 р., склав 76 млрд грн - на 17\% більше, ніж в 2018-му. У 2020 р., як прогнозують експерти, можна очікувати зростання продажів товарів і послуг на $15 \%$, до 87,2 млрд грн. При цьому розмір середнього чека однієї купівлі знизився на 7-10\%, а вартість доставки зросла і становить 5-15\% від вартості товару. У 2020 р. експерти групи EVO очікують ще менше зростання: приблизно на 15\% - до 87,2 млрд грн. [5; 6]. 


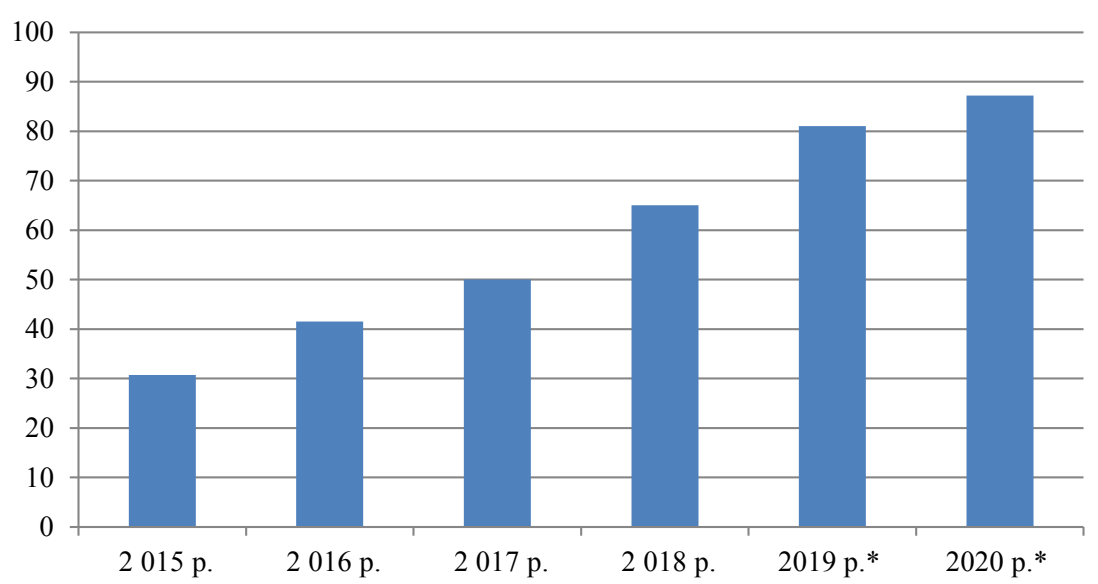

Рис. 2. Стан ринку електронної комерції

Джерело: [2; 3$]$

\section{3. Організація логістичної діяльність в електронній комерції}

Світовий ринок електронної комерції продовжує стрімко розвиватися, і в міру розвитку галузі стає очевидно, що доставка не менш важлива для успіху компанії, ніж будь-який інший аспект бізнесу. Зростання віртуальної онлайн-торгівлі невід'ємно пов'язане з загалом реальною офлайн-логістикою. В останні декілька років логістичні провайдери все частіше виділяють Інтернет-магазини в окремий кліснтський сегмент, масово з'являються спеціалізовані компанії, які обслуговують Інтернет-магазини та компанії, що займаються продажами через сайти. При цьому під логістизацією електронного бізнесу ми розуміємо широке впровадження логістичного підходу, тобто аналізу і синтезу логістичних ланцюгів і систем у рамках віртуалізації економічних процесів.

Проведемо дослідження підходів українських вчених до визначення місця логістики в електронній торгівлі.

Вітчизняні вчені Н.Т. Гриньов, М.В. Кіндій, М.М. Мага [7, с. 576-579] розглядали у своїх роботах електронну комерцію 3 логістичної точки зору. Вони наголошували на тому, що в сучасних ринкових умовах логістичне забезпечення відіграє вирішальну роль у розвитку електронної комерції підприємств. 
М.С. Шкода розкриває у своїх роботах вплив логістичного забезпечення на управління ефективним розвитком підприємства, спираючись на світовий досвід [8, с. 31-36]. Такі українські вчені, як Н.В. Чорнописька та О.В. Солодка, проаналізували взаємозв'язок між розвитком електронної комерції та розвитком ринку послуг логістичного забезпечення. Ці автори також відзначають брак теоретичних досліджень наукової спрямованості у сфері логістичного забезпечення електронної комерції України, низький рівень розвитку ринку логістичних послуг для електронної комерції порівняно із зарубіжними країнами, необхідність застосування кращого досвіду провідних країн [9, с. 490-495]. Автор погоджується з цією точкою зору, але ще відзначає недолік успішних практичних кейсів впровадження логістичних процесів під час організації процесу розвитку електронної комерції українських підприємств.

О.М. Антоненко та І.П. Міщук сформулювали рекомендації для оптимізації логістичної діяльності в електронній торгівлі підприємств для підвищення ефективності їх функціонування [10, с. 349-356].

Для споживачів використання електронної логістики несе наступні вигоди:

- цілодобове обслуговування в будь-який зручний для споживача час, без перерв і вихідних;

- розширення вибору умов замовлення та руху товарів, постачальників, ціни, якості;

- одержання докладної й своєчасної інформації;

- порівняння пропозицій і обмін інформацією з іншими споживачами. Проаналізуємо індекс ефективності логістики в Україні 2010-2018 pp. [19; 20].

Лідерство в рейтингу у Німеччини з сумарним показником LPI Score на рівні 4,2 бала. За нею йдуть Швеція, Бельгія, Австрія і Японія. Другу п’ятірку кращих відкривають Нідерланди, далі йдуть Сінгапур, Данія, Велика Британія та Фінляндія [21].

За попередніми даними дослідження, яке наразі проводить компанія Ukrainian E-commerce Expert, частка підприємств електронної торгівлі серед клієнтів логістичних компаній становить 60-70\%.

Станом на перше півріччя 2019 року в структурі валового поглинання складських приміщень в Київському регіоні домінували представники оптової та роздрібної торгівлі з часткою в 49\%, яка в порів- 
Таблиця 1

Україна за субіндексами LPI 2010-2018 pp.

\begin{tabular}{|c|c|c|c|c|c|c|c|}
\hline \multirow[b]{2}{*}{ Роки } & \multirow[b]{2}{*}{$\begin{array}{c}\text { Загальний } \\
\text { індекс }\end{array}$} & \multicolumn{6}{|c|}{ Субіндекс LPI (місце країни) } \\
\hline & & 昰 & 总 & 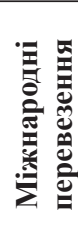 & 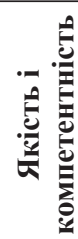 & 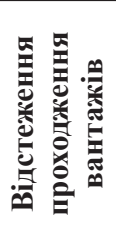 & 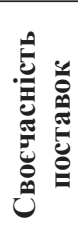 \\
\hline 2010 & $2,57(102)$ & 2,02 & 2,44 & 2,79 & 2,59 & 2,49 & 3,06 \\
\hline 2012 & $2,85(66)$ & 2,41 & 2,69 & 2,72 & 2,85 & 3,15 & 3,31 \\
\hline 2014 & $2,98(61)$ & 2,69 & 2,65 & 2,95 & 2,84 & 3,2 & 3,51 \\
\hline 2016 & $2,74(80)$ & 2,30 & 2,49 & 2,59 & 2,55 & 2,96 & 3,51 \\
\hline 2018 & $2.83(66)$ & 2.49 & 2.22 & 2.83 & 2.84 & 3.11 & 3.42 \\
\hline
\end{tabular}

Джерело: [19]

нянні з 2018 роком зменшилася на 9,9\%. Про це повідомили в компанії CBRE Ukraine.

Стрімкий розвиток електронної торгівлі став причиною збільшенням попиту на послуги логістичних операторів, а саме на використання складських приміщень (зберігання та обслуговування) а також швидку, якісну доставку не тільки по території України, але й за їі межами рис.

Проведемо дослідження основних видів логістичної діяльності в електронній торгівлі (рис. 3).

Інсорсинг має на увазі включення в організаційну структуру компанії власного підрозділу логістики, який надає певний спектр послуг. Така методологія протилежна аутсорсингу, при якому логістичні операції передаються на виконання зовнішньому провайдеру. Однак ці поняття не $\epsilon$ взаємовиключними, тобто можливо їх одночасне застосування, що зустрічається на сьогоднішній день найчастіше.

Обираючи інсорсинг Інтернет-магазин самостійно виконує більшу частину логістичних операцій та є ефективним для малих підприємств, чий масштаб діяльності ще досить невеликий для того щоб залучати зовнішніх логістичних провайдерів. Також ця форма організації логістичних операцій характерна для дуже великих підприємств, які працюють на репутацію і підтримання високої якості, яку вони не завжди можуть контролювати, віддаючи логістику стороннім службам. 


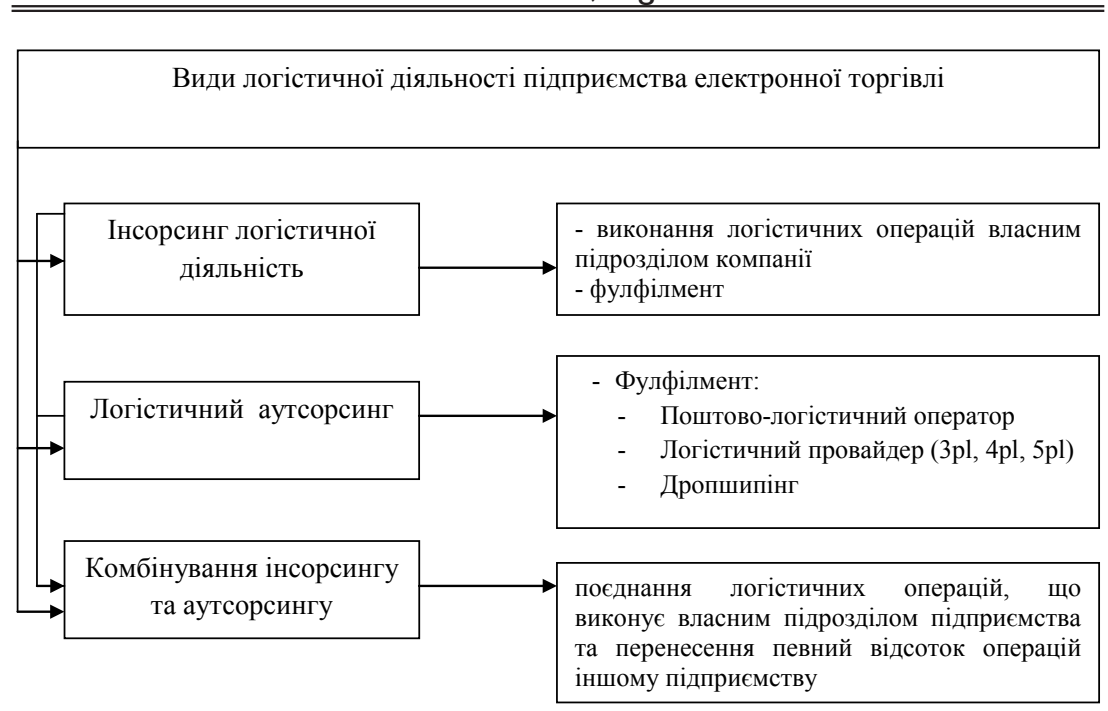

\section{Рис. 3. Види логістичної діяльності підприємства електронної торгівлі}

Джерело: [27]

Однак при використанні інсорсингу підприємству вкрай важливо підготуватися до своєчасної мобільності та гнучкості у випадку розширення діяльності. У міру збільшення кількості замовлень потрібно враховувати необхідність найму більшої кількості персоналу і покупки або оренди додаткових складських приміщень. Крім того, доставка замовлення кінцевого споживача («останньої милі»), як правило, все ж передається на аутсорсинг зовнішнім провайдерам. 3 цією метою до роботи залучаються кур'єрські компанії, служби експрес доставки та поштові сервіси.

Аутсорс дає можливість легко масштабувати бізнес, а також збільшувати географічне охоплення. I якщо в межах одного міста Інтернет-магазин ще якось може вибудувати ефективну службу доставки, то для реалізації товару в регіони і інші країни йому знадобляться посередники [11].

Необхідність аутсорсингу умовно можна виявити по кількості замовлення на день: 
Chapter «Economic sciences»

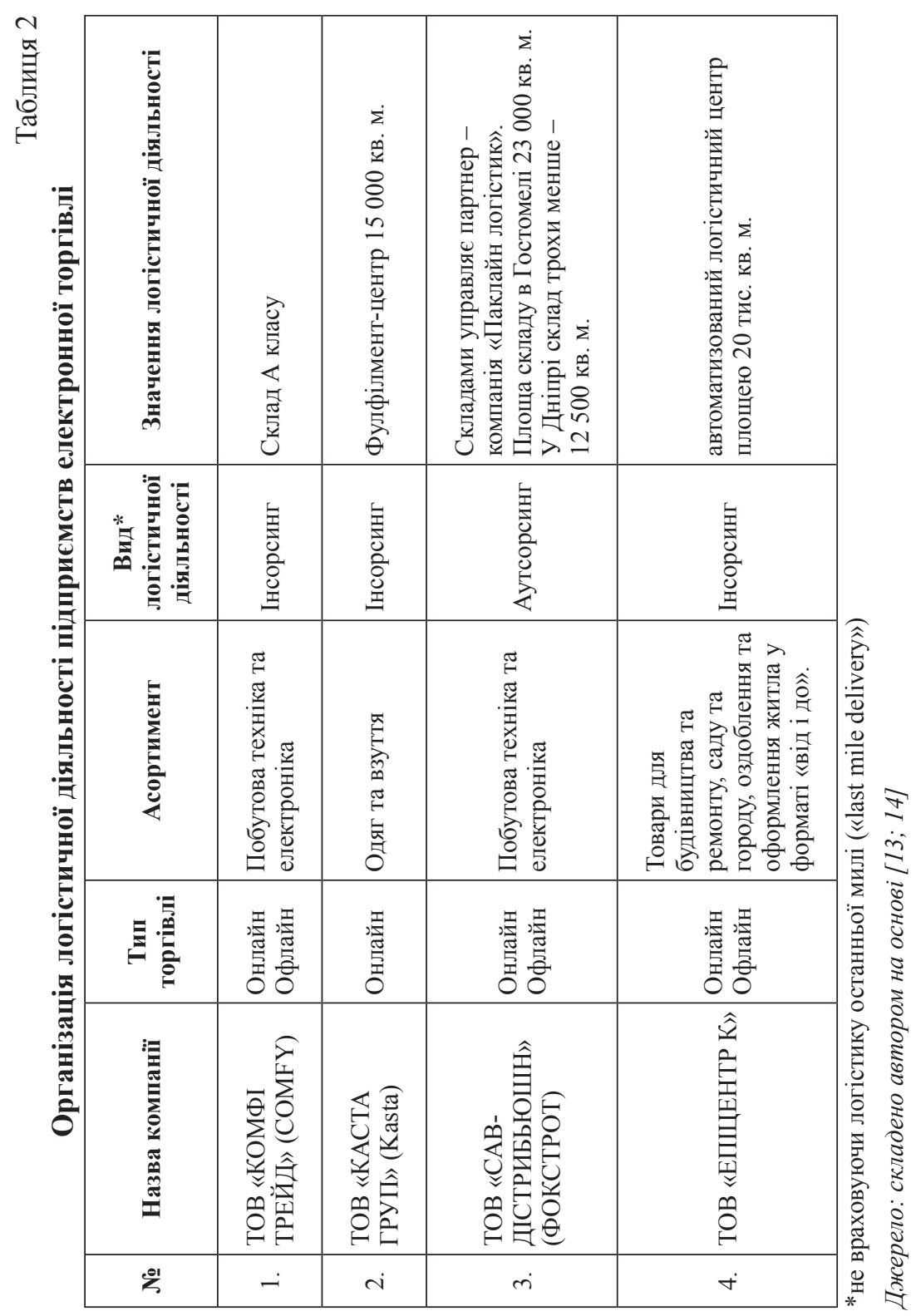


- до 50 замовлень / день - ще не потрібно. Тобто організація виконання логістичних процесів цілком під силу самому Інтернет-магазину. При цьому частина завдань, наприклад доставка, може віддаватися на аутсорсинг.

- від 100 замовлень / день - потрібен.

- від 3000 замовлень / день - вже не потрібен. При таких обсягах доцільніше мати свої потужності, так як власні операції матимуть низьку собівартість, а накопичений досвід в процесі розвитку Інтернет-магазину до такого рівня дозволяє виконувати операції якісно [12].

Отже, таким чином підприємства лідери в 3 категоріях побутова технікка, одяг та товари для будівництва переважно організовують власну логістичну діяльність. Так, наприклад, за результатами 2018 року ТОВ «КОМФІ ТРЕЙД» (Comfy) збільшивши свою частку ринку практично на 10\% та отримавши приріст товарообороту компанії 40\% відмовились від аутсорсингу, аргументуючи це тим, що логістика - ключова фронт-функція, і вона не може бути на аутсорсі, хоча попередній склад підприємства був на аутсорсі.

TOB «КАСТА ГРУП» (Kasta) як найбільший Інтернет-магазин України в fashion-сегменті прийняло рішення про перехід з бізнес-моделі flash sales на модель каталогу з наявністю постійного асортименту товарів. Цей факт спричинив за собою зміни в продуктовій стратегії розвитку компанії: на платформі Kasta.ua, окрім одягу, взуття та аксесуарів, почали з'являтися й інші товари, такі як косметика чи побутова хімія. А зовсім нещодавно онлайн-рітейлер розширив асортимент ще однією популярною в українських Інтернет-покупців групою товарів електронікою і побутовою технікою.

\section{4. Роль доставки в системі електронної комерції}

Час, коли основною конкурентною перевагою Інтернет-магазинів була ціна товару повільно, але йде. I на перший план виходить бажання споживача отримувати не просто дешевий товар, але і сервіс - своєчасну доставку, різні способи оплати, оповіщення, ввічливого кур'єра і т.ін. [1].

Компанія Gemius провела дослідження онлайн-покупців і виявилось, що найбільше незадоволення споживача із діяльності Інтернет-магазину пов'язано із доставкою: 
1.Висока вартість доставки - 29\%.

2. Тривала доставка $-27 \%$.

3. Товар не доставили $-6 \%$.

Стрімкий розвиток логістики в електронній торгівлі сприяв швидкому росту таких сфер, як інформаційні і кредитні послуги, системи електронних платежів, транспортна логістика. Розвиток служби швидкої доставки є одним з типових прикладів. Так, покупцям може сподобатися товар, але якщо їм не подобаються варіанти доставки, вони не будуть його купувати. Якщо запропонувати покупцям більш дешевий варіант оформлення замовлення, вони з великою ймовірністю купуватимуть більше товарів і знову повернуться на сайт. Результат опитування технологічної компанії BigCommerce показують, наскільки тісний зв'язок між роздрібною торгівлею онлайн і доставкою, і наскільки споживачі люблять безкоштовну доставку: 33 тисяч респондентів, які взяли участь в опитуванні, $36 \%$ заявили, що готові навіть відмовитися від алкоголю в обмін на безкоштовну доставку, 25\% повідомили, що відмовилися б від кави, а 22\% - від перегляду контенту Netflix.

За результатами іншого опитування виявилося, що 77\% покупців відмовляються від покупки через незручну доставку, а 58\% припиняють купувати у певних рітейлерів через негативний досвід доставки в минулому. Таким чином, очевидно, що споживачі чітко уявляють собі свої очікування від покупки. Однак більшість постачальників, на жаль, не в повній мірі усвідомлюють, наскільки важливою $є$ правильна доставка для процесу придбання, а тому не приділяють цій частині бізнесу належної уваги.

47\% продавців не знають свого відсотка відмов від Інтернет-кошика, і тим більше не знають, які виникають непорозуміння з кур'єрськими або поштовими службами. Експерти підкреслюють, що ця частина виконання замовлення не менш важлива, ніж інші. Початківцем швидкої і дешевої доставки стала компанія Amazon, яка згодом зробила цю послугу безкоштовною і перевела з формату дводенної до «отримання наступного дня після замовлення».

У даний час на частку Amazon доводиться 49\% всіх онлайн-витрат в Сполучених Штатах. Це 5\% від всіх роздрібних продажів в США. Онлайн-гігант робить величезний тиск на інших ритейлерів і їм це не подобається. Дві третини опитаних продавців переконані, що практика доставки Amazon несправедлива по відношенню до малих підпри- 
ємств. Зараз 22\% продавців в США пропонують клієнтам безкоштовну доставку при покупці будь-якої вартості, а 64\% - при замовленні на певну суму. Це розумно, враховуючи, що 84\% користувачів зазвичай замовляють більше товарів, щоб отримати безкоштовну доставку.

Аналітики заявляють, що безкоштовні послуги для клієнтів не знизять прибуток компанії, якщо на кілька відсотків підвищити ціну товару, запропонувати клієнтам програму лояльності або ввести акційні продукти за нижчими цінами (яких куплять більше). Доставка, на думку експертів, стала важливим елементом будь-якого Інтернет-магазину, i невід'ємною частиною екосистеми електронної комерції [15].

Аналізуючи вищенаведені дані, власникам Інтернет-магазинів необхідно акцентувати свою діяльність саме на організацію доставки та необхідність обирати надійних партнерів, адже різноманітність вибору доставки товарів споживачам лише підтримує його лояльність.

У табл. 3 наведено порівняльні характеристики власної служби доставки та на умовах аутсорсингу [7].

Комплексне рішення для логістичної діяльності, яке може бути як інсорсинг так і аутсорсинг є фулфілмент (від англ. Fulfillment - виконання) - комплекс рішень і операцій з моменту оформлення замовлення покупцем і до моменту отримання ним покупки, переважно для електронної торгівлі [1;2].

Фулфілмент-центр в свою чергу - це логістичний склад, який виконує шість основних операцій: приймання вантажу, зберігання, комплектація, упаковка, доставка, сервіс (робота 3 поверненнями і т.д.). Також слід уточнити, що в українській мові немає аналогічного терміну, який би максимально точно передавав сенс англійського терміна, тому він використовується без перекладу.

На рис. 4 наведено схему використання підприємством електронної торгівлі фулфілменту.

Рішення про використання послуг фулфілменту є гнучким для Інтернет-магазину, оскільки фулфілмент-оператор здатний швидко адаптуватися до змін попиту свого клієнта в залежності від його потреб. Крім того, фулфілмент дозволяє Інтернет-магазину повністю сконцентруватися на маркетинговій діяльності і продажах. Оператор, в свою чергу, розробляє звіти про свою діяльність для клієнта щодо обсягу продажів, кількості повернень, скарг. 


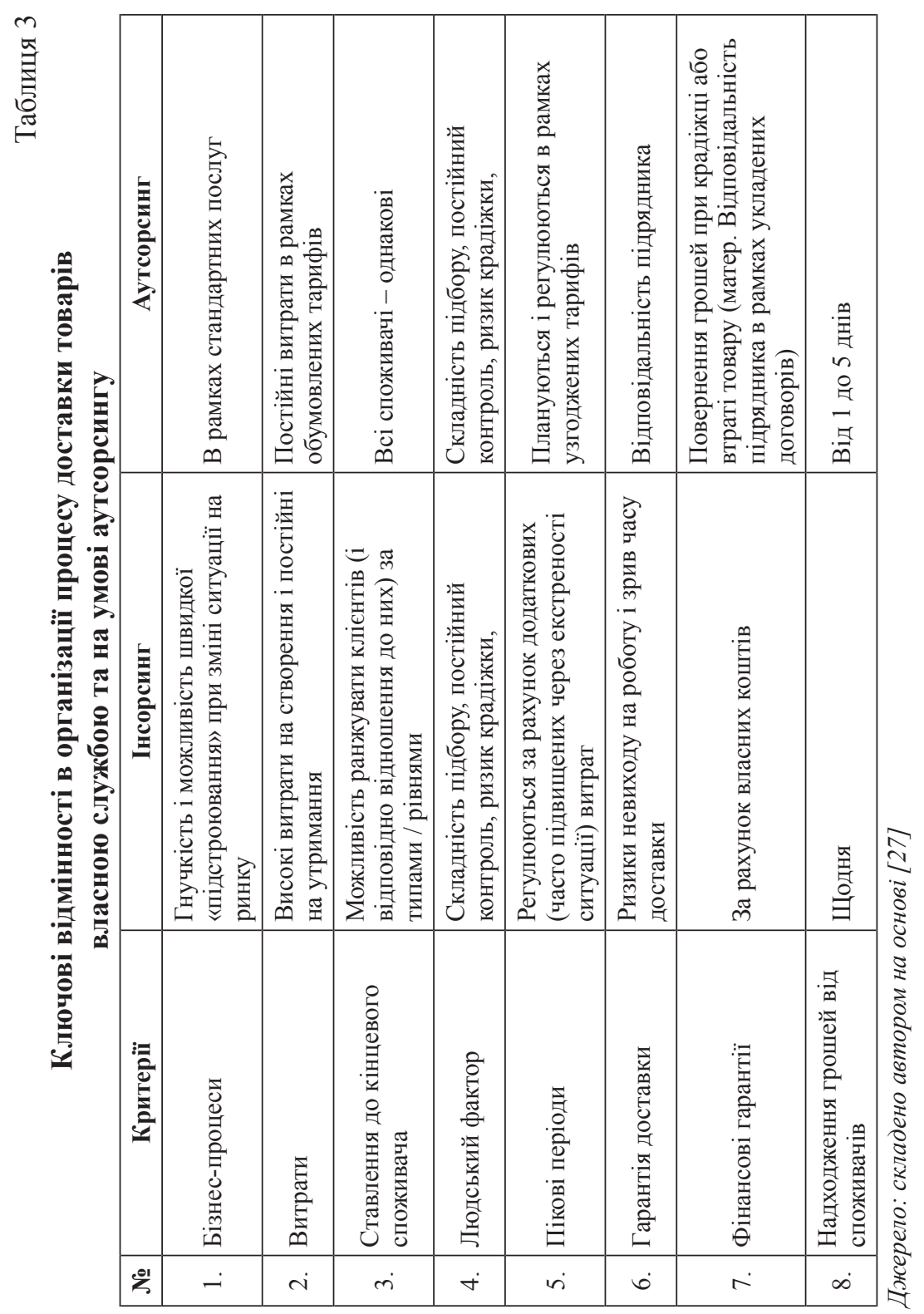




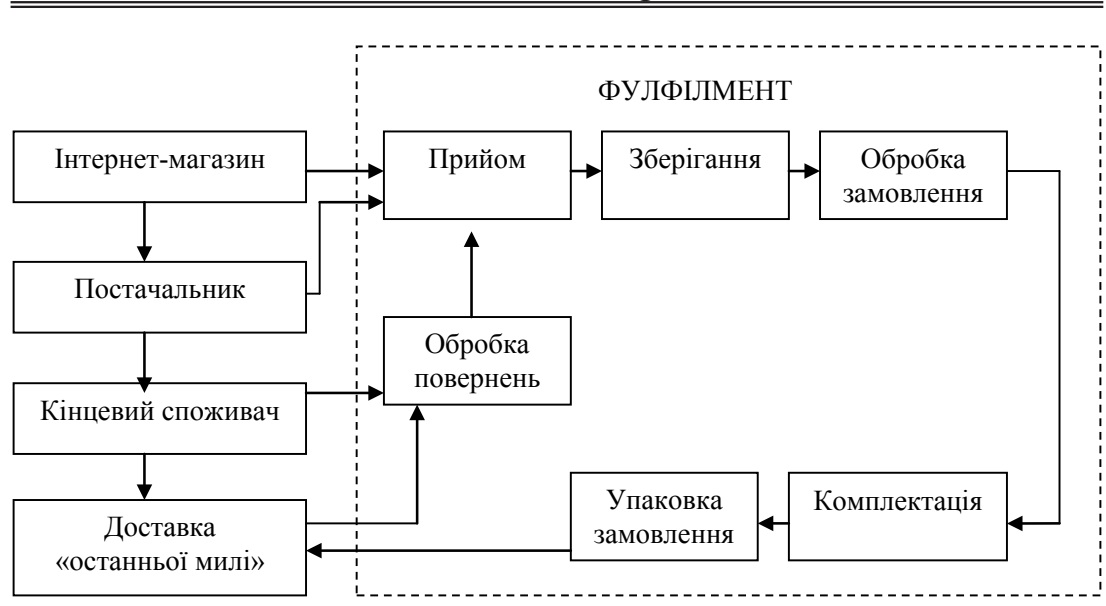

\section{Рис. 4. Схема використання Інтернет-магазином фулфілменту} Джерело: [28]

Споживачами послуг фулфілменту можуть бути:

- Інтернет-магазини - для розширення аудиторії та ринків збуту в США і Європі.

- Постачальники без онлайн - які добре представлені на оптових ринках і бажають оптимізувати канали збуту за рахунок валютних надходжень.

- Іноземні інвестори - бажаючі налагодити поставки продукції від українських виробників.

- Підприємці-експортери - для прискорення процесу доставки та поліпшення свого сервісу.

Використовуючи фулфілмент Інтернет-магазин мінімізує ризики та скорочує операційні витрати на 30-40 \%. Для прикладу, фулфілмент-центр «Віскозна» компанії ТОВ «ЕПІЦЕНТР К»- єдиний в Україні, який працює 3 понад 250 тис. артикулами, в тому числі негабаритним. Ще однією унікальною особливістю фулфілменту є те, що він повністю інтегрований в омніканальну модель продажів. Фулфілмент-центр оснащено сучасною автоматизованою системою управління (WMS-системою) та конвеєрною системою довжиною понад 1,5 км, консольними та спіральними ліфтами, а також двома ділянками 
сортувальної системи. Аналогічна технологія використовується на складах компанії Amazon. Це дозволяє виконувати замовлення з високою точністю та швидкістю - обробка та відвантаження одного транспортного маршруту відбувається менш ніж за 30 хвилин. У результаті, покупець зможе забрати своє замовлення з центру видачі замовлень у ФЦ «Віскозна» вже за пів години, або з будь-якого ТЦ м. Києва через 4 години (надалі час очікування буде зменшено до 2 годин).

Мезонінні та фронтальні системи дозволять зберігати 250 тис. товарних позицій різних габаритних розмірів та обробляти 15 тис. замовлень за зміну, з можливістю збільшення об'ємів обробки замовлень до 60 тис. замовлень на добу. Штат працівників складається з 300 співробітників.

На сьогодні їх можна розділити на основні та додаткові рис. 5.

Також необхідно виокремити аутсорсингові підприємства такі як поштово-логістичні оператори та логістичних провайдерів. Їх різниця полягає в наступному: згідно Закону України «Про поштовий зв'язок » поштовий оператор надає послуги з поштових відправлень, таких як листи з марками, а марки може реалізувати лише Національний оператор поштового зв'язку - в Україні це Українське державне підприємство поштового зв'язку «Укрпошта».

різнопрофільних, хтось на основі довгострокових договорів, хтось час від часу, за необхідності. Провайдери логістичних послуг за кількістю логістичних функцій, а також рівнем доступу до міжнародних і регіональних ринків збуту поділяються по логістичному сервісу [19].

На українському ринку існують ряд логістичних провайдерів, які здійснюють доставку товарів (переважно last mile delivery) як в середині країни, так і за ії межами (міжнародна доставка) (табл. 4).

Лідерами на ринку доставки товарів для Інтернет-магазинів, які забезпечують доставку «останньої милі» $є$ ТОВ «Нова пошта» та ПАТ «Укрпошта». ТОВ «Нова пошта» засновано у 2001 р. - українська компанія, що забезпечує надання послуг експрес-доставці документів, вантажів і посилок для фізичних осіб та бізнесу [5].

Поштомат - це автоматичний поштовий термінал самообслуговування, у якому клієнт може в зручний для нього час самостійно отримувати посилки. Відправник зазначає в декларації адресу поштомата. Коли посилку доставлено в поштомат, одержувач бачить SMS-пові- 


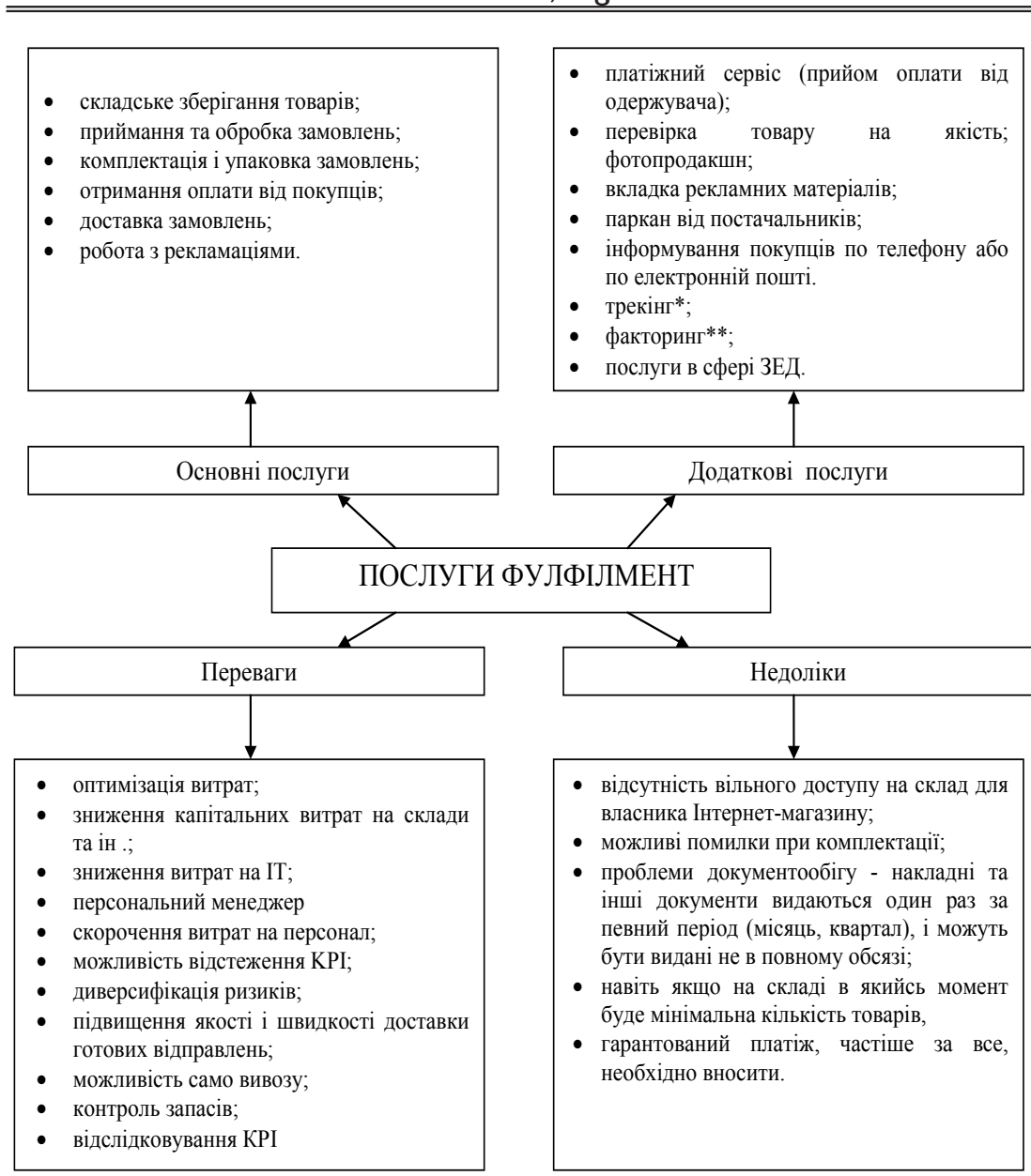

\section{Рис. 5. Послуги фулфіменту в електронній торгівлі, їх переваги та недоліки}

Джерело: складено автором на основі [4; 5; 6; 7]

*Трекінг - це визначення місця розташування рухомих об’єктів в часі за допомогою камери.

** Факторинг - це придбання права вимоги на виконання зобов'язань у грошовій формі за поставлені товари чи надані послуги із прийняттям на себе ризику виконання таких вимог і прийом платежів. 
Таблиця 4 Найпопулярніші логістичні оператори в Україні останньої милі

\begin{tabular}{|c|l|c|c|}
\hline № & Логістичний оператор & Рік заснування & $\begin{array}{c}\text { Кількість об’єктів } \\
\text { видачі, шт }\end{array}$ \\
\hline 1. & Нова пошта & $2001 \mathrm{p}$. & 2300 \\
\hline 2. & Укрпошта & $1994 \mathrm{p}$. & 11.5 тис. \\
\hline 3. & Meest Express & $2005 \mathrm{p}$. & 1915 \\
\hline 4. & Інтайм & $2002 \mathrm{p}$. & 647 \\
\hline 5. & Автолюкс & $1997 \mathrm{p}$. & 200 \\
\hline 6. & Delivery & $2001 \mathrm{p}$. & 290 \\
\hline
\end{tabular}

Джерело: складено автором на основі: [1; 3; 4]

домлення, після чого може забрати відправлення, підтвердивши свою особу через термінал самообслуговування.

На сьогодні масштабні підприємства електронної торгівлі не можуть повністю забезпечити власну логістичну діяльність (інсорсинг), звичайно для «останньої милі доставки» ПЕТ залучають логістичних операторів, ринок яких в Україні активно інвестується задля покращення цього виду сервісу.

\section{5. Висновки}

Отже, основними передумовами розвитку логістичної діяльності підприємства електронної торгівлі $\epsilon$ розвиток обсягів електронної комерції, що складає щороку в середньому $17 \%$ це зумовлює збільшення кількості споживачів Інтернет-торгівлі.

На сьогоднішній день розвиток ринку електронної комерції створює високо конкурентне середовище, яке бореться за кожного споживача. Одним із факторів формування лояльного споживача $є$ надійна та швидка доставка, тому організація логістичної системи на підприємстві електронної торгівлі є дуже важливим.

У статті визначено основні два види організації логістичної діяльності такі як інсорсинг та аутсорсинг та зазначили, що підприємства із замовленнями більш ніж 3000 шт. в день налаштовують власну логістичну систему, наприклад, формуючи фулфілмент-склад. Функції такого складського приміщення не обмежуються тільки розвантаженням, формуванням замовленням, зберіганням, відвантаженням, але й 
виконує ряд додаткових функцій виключно під електронну торгівлю, а саме приймання замовлення із сайту, працюють із поверненнями, фотографують товар.

\section{Список літератури:}

1. Бізнес-моделі в Інтернет бізнесі. Хмельницький національний університет. URL: http://dn.khnu.km.ua/dn/k_default.aspx?M=k1400\&T=01_2\&lng= $1 \& \mathrm{st}=0$ (дата звернення: 31.01.2020).

2. Златьєва Д. Електронний рік: підсумки українського е-commerce за 2017-й. URL: https://rau.ua/novyni/novini-kompanij/e-commerce-2017/ (дата звернення: 26.02.2020).

3. Ринок електронної комерції в Україні в 2015 році виріс на $32 \%$ у гривні. URL: https://www.rbc.ua/ukr/lnews/rynok-elektronnoy-kommertsiiukraine-2015-1468583342.html (дата звернення: 26.02.2020).

4. Не виходячи 3 дому: у 2019 році українці придбали товарів і послуг онлайн на 76 млрд грн. URL: https://rau.ua/ru/news/2019-ukrayintsi-onlajn-76mlrd-grn/ (дата звернення: 25.02.2020).

5. Симоненко К. Тихіше їдеш, далі будеш: підсумки українського e-commerce і логістики за 2019-й. URL: https://rau.ua/novyni/pidsumky-ecommerce-2019/ (дата звернення: 25.02.2020).

6. Електронна комерція як новий економічний об'єкт. URL: https://studopedia.com.ua/1_172495_elektronna-komertsiya-yak-noviyekonomichniy-obiekt.html (дата звернення: 26.02.2020).

7. Гринів Н.Т., Кіндій М.В. Логістика електронної торгівлі в Україні. Вісн. Нац. ун-ту «Львів. політехніка». 2010. № 690. С. 576-579.

8. Шкода М.С. Мировой опыт использования логистических подходов для эффективного управления развитием предприятия и адаптация их к отечественным реалиям. Актуальные проблемы экономики. 2012. № 10(136). С. 31-36.

9. Peter D. Can the E-business execute deliveries? The Economist. 1999. № 9.

10. Антоненко О.М., Міщук І.П., Хамула О.О. Формування систем електронної торгівлі і логістика: теорія та практика організації. Вісн. Наu. ун-ту «Львів. політехніка». 2012. № 749. С. 349-356.

11. 3PL-оператор: практичні поради з організації логістики інтернет-магазину. URL: https://www.miradasklad.ru/blog/post_kak-organizovat-logistiku-vinternet-magazine/ (дата звернення: 26.02.2020).

12. Фулфілмент по-українськи: драйвер або гальмо розвитку ринку. URL: http://tochka365.com.ua/ua/news/fulfilment-po-ukrayinsky-drayver-abo-galmorozvytku-rynku (дата звернення: 26.02.2020).

13. Ігор Хижняк, Comfy: Готуємося впровадити абсолютно новий формат магазинів. URL: https://rau.ua/novyni/hyzhnyak-comfy-novyj-format/ (дата звернення: 25.02.2020).

14. Нагорський В. За лаштунками Kasta: як новий склад компанії відправляє до 50000 замовлень на день (фоторепортаж). URL: https://rau.ua/dosvid/ kasta-novyj-sklad-foto/ (дата звернення: 24.02.2020). 
15. Семенечук О. Роль доставки в системі електронної комерції. URL: https://www.everest.ua/ai-platform/ai-business/rol-dostavki-v-sistemi-elektronnoikomercii/ (дата звернення: 24.02.2020).

16. Епіцентр відкрив свій перший фулфілмент-центр у Києві. URL: https://epicentrk.ua/ua/news/epitsentr-vidkriv-sviy-pershiy-fulfilment-tsentru-ki-vi.html (дата звернення: 26.02.2020).

17. Світовий тренд - фулфілмент - набирає обертів в Україні. URL: http://logist.fm/publications/mirovoy-trend-fulfilment-nabiraet-oboroty-v-ukraine (дата звернення: 26.02.2020).

18. У 2017 році ринок електронної комерції в Україні очікує стрімке зростання. URL: http://i-ua.tv/index.php?newsid=445 (дата звернення: 26.02.2020).

19. Офіційний сайт Світового банку (The World Bank). LPI Report. URL: https://lpi.worldbank.org/ (дата звернення: 25.02.2020).

20. Офіційний сайт Світового банку (The WorldBank). International Score Card of Ukraine. URL: https://lpi.worldbank.org/international/scorecard/ radar/254/C/UKR/2016/C/UKR/2014/C/UKR/2012/C/UKR/2010/C/UKR/2007\# chartarea (дата звернення: 25.02.2020).

21. Шевченко В. Дві третини замовлень логістичних компаній припадають на е-commerce. URL: https://delo.ua/business/dvi-tretini-zamovlen-logistichnihkompanij-pripadaje-na-e-commer-327958/ (дата звернення: 22.02.2020).

22. Україна піднялась на 14 позицій в індексі ефективності логістики Світового банку. URL: https://www.ukrinform.ua/rubric-economy/2508287ukraina-na-66-misci-v-indeksi-efektivnosti-logistiki-svitovogo-banku.html (дата звернення: 22.02.2020).

23. Що таке «пошто мат» і як ним користуватися у відділеннях банку?! URL: https://tusovka.kr.ua/news/2015/04/21/-scho-take-poshtomat-i-jak-nim-koristuvatisja-u-viddilennjah-banku (дата звернення: 22.02.2020).

24. П’ятницька Г.Т., Григоренко О.М. Електронна комерція В2С: розвиток у Східній Європі, ризики та ефект інституціонального витіснення. 2019. С. $122-130$.

25. Канали продажів. URL: http://nikareklama.com.ua/kanali-prodazhiv/ (дата звернення: 26.02.2020).

26. Симоненко К. Nielsen: які чинники впливають на швидкість росту українського i світового е-commerce. URL: https://rau.ua/novyni/nielsenukrayinskogo-e-com/ (дата звернення: 26.02.2020).

27. Що таке аутсорсинг та інсорсинг: правовий лік без. URL: http://loyer.com.ua/ uk/13342-2/ (дата звернення: 26.02.2020).

28. Шалева О.І. Фулфілмент у логістичній інфраструктурі вітчизняної інтернет-торгівлі. Глобальні танаціональні проблеми економіки. 2017. № 19. С. 296-301.

\section{References:}

1. Biznes-modeli $\mathrm{v}$ Internet biznesi. Khmelnytskyy natsionalnyy universytet. URL: http://dn.khnu.km.ua/dn/k_default.aspx?M=k1400\&T=01_2\&lng=1\&st=0 (accessed 31 January 2020). 
2. Zlatyeva D. Elektronnyy rik: pidsumky ukrayinskoho e-commerce za 2017-y. URL: https://rau.ua/novyni/novini-kompanij/e-commerce-2017/ (accessed 26 February 2020).

3. 3 Rynok elektronnoyi komertsiyi v Ukrayini v 2015 rotsi vyris na $32 \%$ u hryvni. URL: Retrieved from: https://www.rbc.ua/ukr/lnews/rynok-elektronnoy-kommertsii-ukraine-2015-1468583342.html (accessed 26 February 2020).

4. Ne vykhodyachy z domu: u 2019 rotsi ukrayintsi prydbaly tovariv i posluh onlayn na $76 \mathrm{mlrd}$ hrn. URL: https://rau.ua/ru/news/2019-ukrayintsi-onlajn-76mlrd-grn/ (accessed 25 February 2020).

5. Symonenko K. Tykhishe yidesh, dali budesh: pidsumky ukrayinskoho e-commerce i lohistyky za 2019-y. URL: https://rau.ua/novyni/pidsumky-e-commerce-2019/ (accessed 25 February 2020).

6. Elektronna komertsiya yak novyy ekonomichnyy ob'yekt. URL: https://studopedia.com.ua/1_172495_elektronna-komertsiya-yak-noviy-ekonomichniy-obiekt.html (accessed 26 February 2020).

7. Hryniv N.T., Kindiy M.V. (2010). Lohistyka elektronnoyi torhivli v Ukrayini. Visn. Nats. un-tu «Lviv. politekhnika», no 690, pp. 576-579.

8. Shkoda M.S. (2012). Myrovoy opyt yspolzovanyya lohystycheskykh podkhodov dlya éffektyvnoho upravlenyya razvytyem predpryyatyya y adaptatsyya ykh $\mathrm{k}$ otechestvennym realyyam. Aktualnye problemy ékonomyky, vol. 10, no 136, pp. 31-36

9. Peter D. (1999). Can the E-business execute deliveries? The Economist, no 9.

10. Antonenko O.M., Mishchuk I.P., Khamula O.O. (2012). Formuvannya system elektronnoyi torhivli i lohistyka: teoriya ta praktyka orha- nizatsiyi. Visn. Nats. un-tu «Lviv. politekhnika», no 749, pp. 349-356.

11. 3PL-operator: praktychni porady z orhanizatsiyi lohistyky internet-mahazynu. URL: https://www.miradasklad.ru/blog/post_kak-organizovat-logistiku-v-internet-magazine/ (accessed 26 February 2020).

12. Fulfilment po-ukrayinsky: drayver abo halmo rozvytku rynku. URL: http://tochka365.com.ua/ua/news/fulfilment-po-ukrayinsky-drayver-abo-galmo-rozvytku-rynku (accessed 26 February 2020).

13. Ihor Khyzhnyak, Comfy: Hotuyemosya vprovadyty absolyutno novyy format mahazyniv. URL: https://rau.ua/novyni/hyzhnyak-comfy-novyj-format/ (accessed 25 February 2020).

14. Nahorskyy V. Za lashtunkamy Kasta: yak novyy sklad kompaniyi vidpravlyaye do 50000 zamovlenna den (fotoreportazh). URL: https://rau.ua/dosvid/kastanovyj-sklad-foto/ (accessed 24 February 2020).

15. Semenechuk O. Rol dostavky $\mathrm{v}$ systemi elektronnoyi komertsiyi. URL: https://www.everest.ua/ai-platform/ai-business/rol-dostavki-v-sistemi-elektronnoi-komercii/ (accessed 24 February 2020).

16. Epitsentr vidkryv sviy pershyy fulfilment-tsentr u Kyyevi. URL: https://epicentrk.ua/ua/news/epitsentr-vidkriv-sviy-pershiy-fulfilment-tsentr-u-ki-vi.html (accessed 26 February 2020).

17. Svitovyy trend - fulfilment - nabyraye obertiv v Ukrayini. URL: http://logist.fm/publications/mirovoy-trend-fulfilment-nabiraet-oboroty-v-ukraine (accessed 26 February 2020). 
18. U 2017 rotsi rynok elektronnoyi komertsiyi v Ukrayini ochikuye strimke zrostannya. URL: http://i-ua.tv/index.php?newsid=445 (accessed 26 February 2020).

19. Ofitsiynyy sayt Cvitovoho banku (The World Bank). LPI Report. URL: https://lpi.worldbank.org/ (accessed 25 February 2020).

20. Ofitsiynyy sayt Cvitovoho banku (The WorldBank). International Score Card of Ukraine. URL: https://lpi.worldbank.org/international/scorecard/radar/254/C/ UKR/2016/C/UKR/2014/C/UKR/2012/C/UKR/2010/C/UKR/2007\#chartarea (accessed 25 February 2020).

21. Shevchenko V. Dvi tretyny zamovlen lohistychnykh kompaniy prypadayut na e-commerce. URL: https://delo.ua/business/dvi-tretini-zamovlen-logistichnih-kompanij-pripadaje-na-e-commer-327958/ (accessed 22 February 2020).

22. Ukrayina pidnyalas na 14 pozytsiy $\mathrm{v}$ indeksi efektyvnosti lohistyky Svitovoho banku. URL: https://www.ukrinform.ua/rubric-economy/2508287-ukraina-na-66-misci-v-indeksi-efektivnosti-logistiki-svitovogo-banku.html (accessed 22 February 2020).

23. Shcho take «poshtomat» i yak nym korystuvatysya u viddilennyakh banku?! URL: https://tusovka.kr.ua/news/2015/04/21/-scho-take-poshtomat-i-jak-nim-koristuvatisja-u-viddilennjah-banku (accessed 22 February 2020).

24. Pyatnytska H.T., Hryhorenko O.M. (2019). Elektronna komertsiya vs: rozvytok u skhidniy yevropi, ryzyky ta efekt instytutsionalnoho vytisnennya, pp. $122-130$.

25. Kanaly prodazhiv. URL: http://nikareklama.com.ua/kanali-prodazhiv/ (accessed 26 February 2020).

26. Symonenko K. Nielsen: yaki chynnyky vplyvayut na shvydkist rostu ukrayinskoho i svitovoho e-commerce. URL: https://rau.ua/novyni/nielsen-ukrayinskogo-e-com/ (accessed 26 February 2020).

27. What is outsourcing and outsourcing: legal liberty. URL: http://loyer.com.ua/ en/13342-2/ (accessed 26 February 2020).

28. Shaleva O.I. (2017). Fulfilment in Logistics Infrastructure of Domestic Internet Commerce. Global and national problems of the economy, no 19, pp. 296-301. 